\title{
The Changing Face of Europe
}

\author{
Alain Lamassoure ${ }^{1}$ \\ European Parliament
}

Human history often rhymes with mystery. One of the deepest mysteries in the history of our time hides behind the ongoing process of what is called 'the European construction'. An open-ended and never ending process. With stages of slowing down, followed by dramatic moves forward, but always irresistible. The small, timid, infant Common Market of the Six has deepened to a full economic and monetary union and enlarged to almost the whole European continent. It took us half a century: eternity for a man, but one second for mankind.

What has been achieved for this half-century?

We have carried out two historic, unprecedented achievements.

First. Securing peace among ourselves. Peace and reconciliation. The depth of reconciliation between our peoples is unbelievable. Let me take an example: my grandmother. Her father fought against the Germans in the year eighteen seventy. Her husband fought against the Germans in nineteen fourteen. Her son and son-inlaw - my father - fought against the Germans in nineteen thirty nine. And to-day, when asked 'what people is the closest to, or the best friend of the French people', two French out of three answer: 'The German people, of course!' And conversely. It is as though, let us say in twenty years time, the Israeli would answer: 'The Palestinians', or the Indians 'the Pakistanis". This miracle is the masterpiece of the Union: it was achieved by dint of coming together, working together, bringing together our political, economic, administrative elite, our academics and students, and even our localities through tens of thousands of local partnerships.

The second historic success is the monetary union. And it was no mean achievement. A necessary pre-condition was to put our public finances in order: they were unbalanced everywhere and the economic conjuncture was hardly helpful in the nineties. Everywhere the unpopular but necessary fiscal policies were launched and pursued. Therefore, everywhere the outgoing governments were voted out in the next national elections, and nevertheless, everywhere the new majority taking over resumed these unpopular policies. So that, at the end of the day, they were twelve of us in the monetary union. The socialists as well as the conservatives, the

1 Avtor je ugledna politična osebnost v Franciji, kot prejšnji minister za evropske zadeve in finance, kot sedanji poslanec $v$ evropskem parlamentu in predstavnik francoske vlade $v$ evropski konvenciji. Pričujoči referat je predstavil na Dnevih slovenske uprave v septembru 2003. Zaradi njegove aktualnosti ga objavljamo tudi v slovenskem prevodu. 


\section{Alain Lamassoure \\ The Changing Face of Europe}

liberals like the Christian-democrats: all ruling political parties in twelve States preferred to lose power rather than putting the monetary union at risk. Europe first.

What does that prove? How deeply rooted the European sentiment is, in our countries. These statesmen were no heroes. They were, and still are, good average politicians in their home countries. But they knew that, in front of their national pubic opinion, they could not afford to endanger in any way the European dream.

To-day, with the accession by the eastern European countries, time has come to draw up a balance sheet of the process, and review both the competencies of the Union and its decision-making process to meet the requirements of the world in the 21st century. This review has been bestowed by the European leaders to a European Convention, named after the Philadelphia Convention. Being now at the end of our proceedings, what can we expect from their outcome? I would make three points.

1. The Convention has opened a new era for Europe. It will be a new Europe.

To-day's European Union is a weird political animal, an alien in the 'political zoo'. All of us keep repeating the E.U. is not a State. All right, it is not a State, but it has enormous political power of its own: considerable legislative powers - the French Supreme Court once assessed that every year, $60 \%$ of new legal rules imposed on the French citizens are decided upon in Brussels and no longer in the French National Assembly, and the proportion is bound to be the same in the other member States. The E.U. is not a State, but it has a budget of EUR 100 billion. This same non-State has a single currency, which my country is now deprived of. When commercial issues are debated in the World Trade Organisation, it is no longer my national Government which represents my national interests, but the European Commission. This non-State is even in the process of acquiring military capability.

For historical reasons the Union has developed with very different institutions and ground rules from those of traditional political entities such as States or territorial authorities.

- There is something called 'European Parliament', elected by universal suffrage. But for long it has been more a consultative forum than a legislative body.

- The legislative power pertains to a body named 'Council of Ministers', which represents national governments.

- In spite of the name, the Ministers are not the executive of the Union. This is the task of the Commission, a novel form of institution. The Commission is responsible for expressing the Union's common interest. It has an exclusive right of legal initiative. It also has certain quasi-judicial functions. Its members are appointed, and their status is more that of a board of very senior experts than politicians.

Over time, this improbable system has become more and more cumbersome, and less and less efficient. So that the Convention has to take into account two major changes: the revolution of numbers, and the revolution of the people. 


\section{Alain Lamassoure \\ The Changing Face of Europe}

Revolution of numbers. The institutions we have retained since 1957 were designed for the little 'Common Market' of the six founding States. Around that table, unanimity was not too difficult to achieve. But with twenty-five or thirty members, to require unanimity would be a commitment to inaction. That applies to political decisions, to the drafting of laws, and to the institutional reforms themselves.

Likewise, the time is ripe for the revolution of the people. Hitherto, Europe has been able to come together almost without reference to its peoples. Surprisingly, public opinion has hardly been consulted: events have taken place as if European construction, and even the functioning of the Community authorities, had been hijacked by a specialised ruling class.

Those days are over. For one simple, single reason. The new founding text that will emerge from the proceedings of the Convention will be impossible to ratify in a great many Member States - France, for one - without recourse to a referendum. The Union will be democratic or it will not survive. Before casting their vote, the citizens will want at least to understand the text, to make out what Europe is for - the distribution of competencies - and to secure somehow their final say in the system.

Thus, whatever the philosophy adopted, the revolution of numbers is in itself sufficient to compel the Union to adopt the majority decision procedure and the revolution of the people will compel us to the creation of an executive powera 'Mr Europe' or 'Mrs Europe'.

\section{The new step forward: from an economic area to a political one.}

For the sake of simplification, I would say that so far the E.U. has developed as a common economic and monetary area, equipped with legislating powers in these fields.

Among the Convention, a wide consensus is setting in to change this economic area into a fully political area, ruled by dedicated authorities enjoying democratic legitimacy of their own.

The overall design should most probably be based on the federal model, but should take account of the European Union's special characteristics, in particular:

- The fact that the Union does more than just exercise the powers that have been transferred to it: it also co-ordinates many of the Member States' national policies. This is a novel feature (it is practically non-existent in the US federal system) which is generally poorly understood and yet is extremely useful, since it means that our governments are gradually developing a sort of universal, permanent benchmarking.

- The wide range of Member States in terms of wealth, demography, size and languages is considerably greater than in existing federations, except perhaps for the Indian Union. 


\section{Alain Lamassoure \\ The Changing Face of Europe}

What does that mean?

- In the distribution of competencies, the role of the Union will be enlarged to all the issues related to the movement of the people: asylum and immigration policy, fight against cross-border crime, including terrorism, drug-running and prostitution. We are going to introduce in the constitution the legal bases for the creation, in due time, of a European FBI and a European Prosecutor.

Let me underline that if the normative power of the Union will expand, the fiscal and taxation power will remain in the hands of national States. The common European budget is capped at 1 per cent of our global GDP. The Union of 450 million inhabitants will keep a budget of a country like The Netherlands - 15 millions. Which implies that each individual member State will remain the area of redistribution between the wealthy and the destitute, between juniors and seniors, between the ailing people and those in good health. It is a major difference from the classical federal models in the US, Canada, Germany.

- But when it comes to the institutions and the decision-making process, we will refer to the classical federal pattern. Two chambers in charge of lawmaking: the European law shall be adopted by a majority in the Parliament, representing the citizens, and a majority in the Council, representing the States. The executive authority will stem from the current Commission. Its President will be elected by the citizens through the European Parliament, along the lines of a national parliamentary system.

3. The political debate that the Convention has raised but that it will not conclude is: should this political area change further into a political power, political might?

Do we have the will and capacity, not only to live together, but also to act together, including on the global stage ? Do we see the European authorities more as an arbiter, a referee, a supervisory body encouraging the good and blaming the bad guys, or as genuine and fully-fledged policy-makers within their sphere of competencies? The latter was the original vision of our 'Founding Fathers' in the fifties, and it still prevails among the Six founding States. But there are still clearly differing views among the current governments. This debate clearly needs further ripening.

That is why our text will be the last European treaty, and the first Constitution, but not the last Constitution for Europe.

Hence, the idea of grafting into the genetic code of this so-called Constitution the genes for further mutations ahead.

On economic policy, we will not have one single economic policy for the 25 States, but the euro-zone members will be allowed to enhance co-operation among themselves and to seek one single representation in all international 


\section{Alain Lamassoure \\ The Changing Face of Europe}

financial institutions. I am looking forward to interesting comments from somewhere near the Potomac River.

On foreign and defence policy, the Iraq crisis was a dramatic moment of truth. We must take into account that not all governments are willing to grant the Union a role in foreign or/and defence policy. Not yet. Therefore, we will try to devise a dual Europe but within the same legal and political framework.

- A wider Europe, with twenty-five, and later thirty or more, members, making up the political area of the life in common.

- And inside that one, a hard core, a vanguard, comprising several pioneering States but open to all others, aiming at a European political power. This vanguard could try to go deeper into political integration, and to pool more competencies, particularly in foreign and defence issues. But these further competencies would be exerted within the same European institutions. Thus, the other member States would be present, for instance, around the table of the European Council, without the right to cast a vote on these extra-issues, but with the ability to express their views. And with the European Commission in a position to recall, if need be, what the interest of the wider Europe is.

\section{PREVOD}

\section{Evropa spreminja svoj obraz}

Svetovni dogodki so pogosto zagonetka. In tako je ena od največjih zagonetk sodobne zgodovine razvoj tako imenovane »izgradnje Evrope«. Negotov in nikoli dokončan proces, ki se včasih upočasni, potem pa spet dramatično požene naprej in nezadržno napreduje. Mali, skromni, skoraj otroški Skupni evropski trg šestih držav se je razširil v polno gospodarsko in denarno unijo, povečal se je skoraj na ves evropski kontinent. To je trajalo pol stoletja: večnost za človeka, ena sekunda za človeštvo.

Kaj smo uresničili v tega pol stoletja?

Dva zgodovinska dosežka brez primere.

Predvsem, vzpostavili smo mir. Mir in spravo. Neverjetno, kako globoka je sprava med našimi narodi. Poglejmo mojo staro mamo. Njen oče se je bojeval proti Nemcem v letu 1870. Njen mož se je bojeval proti Nemcem v letu 1914. Njen sin in njen zet - moj oče - sta se bojevala proti Nemcem v 1939. In če danes vprašate: kateri narod je najbližji, najboljši prijatelj Francozom?, odgovorita dva Francoza od treh "Seveda Nemci! « In obratno. To je tako, kot če bi denimo čez dvajset let Izraelci odgovorili, da so njihovi najboljši prijatelji Palestinci, Indijci pa, da so to Pakistanci. Ta čudež je prava mojstrovina Unije: ustvarili smo ga tako, da smo stopili skupaj, sodelovali, združili politično, gospodarsko in upravno elito, akademike in študente in celo pokrajine $v$ deset tisoč skupnih projektih. 


\section{Alain Lamassoure \\ The Changing Face of Europe}

Drug zgodovinski uspeh je monetarna unija. Kar ni bil majhen dosežek. Potrebni, temeljni pogoj zanj je bila ureditev povsod neuravnovešenih javnih financ; ekonomske razmere $v$ devetdesetih letih pa $k$ temu niso posebno pripomogle. Morali smo oblikovati in izvajati nepriljubljene toda nujno potrebne fiskalne politike. Tudi zato so vsepovsod tedanje vlade izgubljale na volitvah; kljub temu so nove večinske vlade nadaljevale $s$ to nepriljubljeno politiko. Tako da nas je bilo slednjič $v$ denarni uniji dvanajst: socialisti in konservativci, liberalci in krščanski demokrati; vse politične stranke $v$ dvanajstih državah bi rajši izgubile oblast, kot da bi tvegale uspeh denarne unije. Evropa je bila na prvem mestu.

To dokazuje, kako globoko je $v$ naših državah ukoreninjeno čustvo pripadnosti Evropi. Naši državniki niso bili heroji. Bili so, in še zmeraj so, dobri, povprečni politiki $\checkmark$ svojih državah. Toda vedeli so, da si spričo domačega javnega mnenja ne morejo privoščiti, da bi sen o Evropi kakorkoli ogrozili.

Danes, ko pristopajo vzhodno evropske države, je prišel čas, da napravimo bilanco tega procesa in ocenimo pristojnosti unije in odločanje $v$ njej, da bi videli, kako ustrezajo zahtevam enaindajsetega stoletja. To presojo so evropski voditelji dodelili Evropski konvenciji, imenovani po Philadelphijski konvenciji. Ker se dogovori bližajo h koncu, poglejmo, kaj lahko pričakujemo od rezultata. Navedel bom tri ugotovitve.

\section{Konvencija odpira novo dobo za Evropo. To bo nova Evropa.}

Današnja Evropska unija je čudna politična žival, tujec $v$ "političnem živalskem vrtu«. Vsi nenehno ponavljamo, da unija ni država. Res, ni država, ima pa velikansko politično moč: znatno zakonodajno moč - francosko vrhovno sodišče je nekoč izjavilo, da se vsako leto $60 \%$ novih zakonskih določb, ki veljajo za francoske državlja$n e$, določa $v$ Bruslju in nič več $v$ francoskem parlamentu. Ta odnos je verjetno enak $\checkmark$ drugih državah članicah. Unija ni država, ima pa proračun 100 milijard EUR. Prav ta nedržava ima svojo državno valuto, ki je zdaj moja država nima več. Kadar se v WTO razpravlja o gospodarskih vprašanjih, državnih interesov ne zastopa več vlada moje države, temveč evropska komisija. Ta nedržava je celo pričela oblikovati lastno vojaško silo.

Zelo različne institucije in temeljna zakonodaja od tistih $v$ tradicionalnih političnih entitetah, kot so državne ali teritorialne oblasti, so se razvile $v$ uniji iz zgodovinskih razlogov.

- Obstaja nekaj, kar se imenuje "Evropski parlament«, izvoljen z neposrednimi volitvami, že dolgo bolj posvetovalno kot zakonodajno telo.

- Zakonodajna oblast pripada svetu ministrov, ki predstavlja nacionalne vlade.

- Kljub svojemu imenu, ministri niso izvršilna oblast unije. To je naloga komisije, nove oblike institucije. Komisija je odgovorna za uresničevanje skupnega interesa Unije. Ima izključno pravico zakonskih pobud. Ima tudi nekaj drugih sodnih 


\section{Alain Lamassoure \\ The Changing Face of Europe}

funkcij. Njeni člani so imenovani, njihov status pa je bolj podoben odboru pomembnih strokovnjakov kot politikov.

Sčasoma postaja ta nenavadni sistem vse bolj okoren in vedno manj učinkovit. Tako da mora konvencija upoštevati dve veliki, revolucionarni spremembi: spremembo števila in spremembo ljudi.

Drastična sprememba števila. Institucije, ki izhajajo še iz leta 1957, so bile namenjene malemu Skupnemu trgu šestih držav ustanoviteljic. V njihovem krogu ni bilo težko doseči soglasja. Toda pri petindvajsetih ali tridesetih članih bi zahteva za soglasje pomenila priznavanje nedelovanja. Tako za politične odločitve, kot za osnutke zakonov in za reforme institucij.

Enako je čas dozorel tudi za upoštevanje ljudi. Do zdaj se je Evropa lahko združevala, skoraj ne da bi se ozirali na ljudi. Presenetljivo je, da so redko posvetovali z javnim mnenjem: odločanje o zgradbi Evrope in celo delovanju organov v skupnosti je tako rekoč ugrabil poseben vladajoči razred.

Ta čas je minil. Iz enega samega, preprostega razloga. Novo ustavno besedilo, ki bo izhajalo iz določil konvencije, bo $v$ številnih državah članicah nemogoče ratificirati, na primer v Franciji, ne da bi izvedli referendum. Unija bo morala biti demokratična ali pa ne bo preživela. Preden se bodo odločali, bodo hoteli državljani vsaj razumeti besedilo, dognati, za kaj gre $\vee$ Evropi - kako so razporejene pristojnosti in so nekako zagotoviti svoj končni da v sistemu.

Torej, ne glede na privzeto filozofijo bo samo sprememba števila članic zadoščala, da bo morala Unija prevzeti večinsko odločanje, upoštevanje ljudi pa nas bo prisililo, da oblikujemo izvršilno oblast - torej gospoda ali gospo Evropo.

\section{Nov korak naprej: iz gospodarskega $v$ politično območje}

Da poenostavimo, bi rekel, da se je evropska unija do zdaj razvijala kot skupno gospodarsko in monetarno območje, opremljeno z zakonodajno oblastjo na teh področjih.

Z konvencijo se uveljavlja široko soglasje, da bi se to gospodarsko območje spremenilo $v$ polno politično, z demokratično legitimnimi organi.

Okvirni načrt bo verjetno moral temeljiti na federalnem modelu, upoštevati pa bo moral tudi nekatere evropske značilnosti, zlasti:

- Dejstvo, da unija opravlja več kot samo to, kar je bilo preneseno na njo: razen tega koordinira številne državne politike držav članic. Ta nova funkcija (ki praktično ne obstaja $\vee$ ameriškem federalnem sistemu) je na splošno slabo razumljena in vendar izredno koristna, ker pomeni, da naše vlade postopno razvijajo neke vrste splošno, medsebojno primerjalno analizo.

- Kar zadeva zdravstvo, populacijo, velikost in jezike, je skupna velikost držav članic znatno večja kot $v$ drugih, obstoječih federacijah, razen morda $v$ Indijski uniji.

Kaj to pomeni? 


\section{Alain Lamassoure \\ The Changing Face of Europe}

- Pri razdelitvi pristojnosti se bo vloga unije povečala na vsa vprašanja, ki se nanašajo na gibanje ljudi: azilno politiko in politiko priseljevanja, boj s čezmejnim kriminalom, tako tudi s terorizmom, prometom z drogami in prostitucijo. $V$ ustavo bomo uvedli zakonsko osnovo, ki bo nekega dne omogočila vzpostavitev evropske zvezne policije in imenovanje evropskega tožilca.

- Naj poudarim, da se bo normativna moč unije povečevala, fiskalno in davčno odločanje pa bosta ostala $\vee$ pristojnosti držav članic. Skupni evropski proračun je omejen na en odstotek skupnega bruto domačega proizvoda.Torej bo unija 450 milijonov prebivalcev imela proračun kot država Nizozemska - 15 milijonov. Kar pomeni, da bo vsaki državi članici ostalo področje prerazdelitve sredstev med bogatimi in revnimi, med mladimi in starimi, med bolnimi in zdravimi. To je velika razlika glede na klasične federalne modele $v$ ZDA, Kanadi in Nemčiji.

- Toda ko gre za institucije in odločanje, se bomo sklicevali na klasični federalni vzorec. Za zakonodajo bosta zadolžena dva doma: evropsko zakonodajo bosta sprejemala z večino parlament, ki predstavlja državljane, in svet, ki predstavlja države. Izvršilna oblast bo izhajala iz sedanje komisije. Njen predsednik bo izvoljen od državljanov prek evropskega parlamenta, usklajeno s postopkom nacionalnih parlamentarnih sistemov.

3. Konvencija je odprla politično razpravo, ki se še ne bo končala: ali naj se naše politično območje spreminja $\vee$ politično moč, politično silo? Ali sta $\vee$ nas volja in sposobnost, da bomo ne samo živeli skupaj, temveč tudi delovali skupaj, medsebojno in $\vee$ globalni razsežnosti? Ali pričakujemo, da bodo evropske oblasti bolj neke vrste razsodniki, ocenjevalci, nadzorno telo, ki bo spodbujalo dobre in karalo slabe, ali pa pravi in opolnomočeni strategi v krogu svojih pooblastil? Prav slednje je bilo prvotna vizija "ustanoviteljev « v petdesetih letih in kot tako še zmeraj obstaja med šestimi ustanoviteljicami državami. Med sedanjimi vladami pa je o tem že veliko različnih mnenj. Očitno bo o tem treba še veliko razpravljati.

Zato bo naše besedilo konvencije zadnja evropska mednarodna pogodba in prva, toda nikakor ne zadnja evropska ustava.

Odtod zamisel, da bi vgradili v gensko kodo te tako imenovane ustave gene za kasnejše mutacije.

O gospodarski politiki, kjer ne bomo imeli ene same gospodarske politike za 25 držav, temveč bodo evropske članice lahko pospeševale medsebojno sodelovanje in bodo iskale eno samo zastopstvo $v$ vseh mednarodnih finančnih institucijah. Zanima me, kakšne pripombe na to bomo slišali iz krajev ob reki Potomac.

Glede zunanje in obrambne politike je bila kriza $\vee$ Iraku dramatičen trenutek resnice. Upoštevati moramo, da niso vse vlade pripravljene podeliti uniji vlogo $v$ zunanji in obrambni politiki. še ne. Zato bomo poskušali $\vee$ istem pravnem in političnem okviru zgraditi Evropo v dveh delih: 


\section{Alain Lamassoure \\ The Changing Face of Europe}

- Širša Evropa, s petindvajsetimi in kasneje mogoče tridesetimi članicami, ali celo več, si bo oblikovala politično območje skupnega življenja.

- Znotraj bo trdno jedro, avantgarda, ki bo zajemala številne pionirske države, pa hkrati odprta za vse druge, ki bodo ciljale na evropsko politično moč. Ta avantgarda bo poskušala doseči večjo politično integracijo in zbrati več pristojnosti, zlasti glede vprašanj zunanje politike in obrambe. Toda te pristojnosti se bodo izvajale $v$ istih, evropskih institucijah. Tako bodo na primer države članice prisotne na sejah evropskega sveta, s pravico glasovanja pri teh posebnih vprašanjih in z možnostjo izražanja svojega mnenja. In imeli bomo evropsko komisijo, ki bo po potrebi opominjala, kakšni so interesi širše Evrope. 